\title{
Reagent for the Enzymatic Determination of Serum Total Triglycerides with Improved Lipolytic Efficiency
}

\author{
By U. Nägele, E. O. Hägele, G. Sauer, E. Wiedemann, P. Lehmann, A. W. Wahlefeld and W. Gruber
}

Boehringer Mannheim GmbH Biochemica Werk Tutzing

(Received July 6/October 31, 1983)

Summary: A fully enzymatic assay is described for the determination of triglycerides. The coupled activities of triacylglycerol acylhydrolase and glycerol kinase result in the formation of glycerol-3-phosphate. The system also contains $L$ - $\alpha$-glycerol-phosphate oxidase, which produces hydrogen peroxide from glycerol-3-phosphate, and a sensitive chromogenic indicator system, consisting of peroxidase, 4-chlorophenol and 4-aminophenazone. We evaluated this method with respect to kinetics, linearity, blank rates, precision, accuracy, reagent stability and interfering substances.

The accuracy of the triglyceride assay demands that each enzymatic reaction step be complete and homogeneous. We therefore developed HPTLC- ${ }^{1}$ ) and HPLC- ${ }^{2}$ ) methods to monitor the course and completeness of each step.

Reagenz zur enzymatischen Bestimmung von Triglyceriden im Serum mit verbesserter lipolytischer Wirksamkeit

Zusammenfassung: Es wird ein vollenzymatischer Test zur Bestimmung von Triglyceriden beschrieben, dessen Prinzip auf der Freisetzung von Wasserstoffperoxid aus Glycerin-3-phosphat mittels $L$ - $\alpha$-Glycerinphosphatoxidase in Kombination mit einem empfindlichen Farbindikator-System, bestehend aus Peroxidase, 4-Chlorphenol und 4-Aminophenazon, beruht. Diese Methode wurde hinsichtlich Reaktionsgeschwindigkeit, Linearitätsbereich, Reagenzleerwert, Präzision, Richtigkeit, Reagenzstabilität und interferierender Substanzen untersucht.

Da die Rịchtigkeit der Bestimmung von Triglyceriden einen vollständigen und eindeutigen Verlauf jedes einzelnen enzymatischen Reaktionsschrittes voraussetzt, wurden zur Verlaufskontrolle der einzelnen Teilreaktionen HPTLC ${ }^{1}$ )- sowie HPLC ${ }^{2}$ )-Methoden entwickelt.

\section{Introduction}

Fully enzymatic methods have considerably increased the practicability of routine methods for the assay of triglycerides. In the most widely used modification (1) glycerol is liberated from triglycerides by treatment with lipase and esterase. The resulting glycerol undergoes subsequent enzymatic reactions, which are monitored spectrophotometrically in the

1) HPTLC = High Performance Thin Layer Chromatography

2) HPLC = High Performance Liquid Chromatography visible or ultraviolet range; these reactions include oxidation or phosphorylation/oxidation. The initial oxidation of glycerol has been reported to be catalysed by nucleotide dependent enzymes (e.g. glycerol dehydrogenase, EC 1.1.1.6 or EC 1.1.1.72) (2). An enzyme which oxidizes glycerol to glyceraldehyde with no requirement for an exogeneous cofactor has been described (3), whereas glycerol phosphate may be oxidized by several different enzymes (e.g. glycerol-phosphate dehydrogenase $\left(\mathrm{NAD}^{+}\right)$, EC 1.1.1.8, or glycerolphosphate oxidase, EC No. not assigned) $(2,4)$. 
Monitoring the decrease of NADH concentration in the ultraviolet range is a method of high precision, sensitivity and specifity but has disadvantages concerning stability of the working solution. Furthermore a parallel sample blank must be measured for each sample to calculate the UV-absorbance of serum components. Colorimetric methods, based on the reduction of tetrazolium salts by NADH and diaphorase and measurement of the resulting formazan in the visible region (5), need no parallel sample blank but suffer from increasing reagent blanks caused by spontaneous formation of the formazan dye.

The recent description of $L$ - $\alpha$-glycerol-phosphate oxidase (4) and its use for the determination of triglycerides (6-9) has prompted us to combine this enzyme, which produces hydrogen peroxide, with a sensitive chromogenic system, based on the method reported by Trinder (10).

In this fully enzymatic assay, triglycerides are cleaved by triacylglycerol acylhydrolase (EC 3.1.1.3) and the glycerol obtained is phosphorylated with ATP and glycerol kinase (EC 2.7.1.30) into glycerol-3-phosphate, which is oxidized by glycerol-phosphate oxidase (EC No. not assigned) to dihydroxyacetone phosphate and hydrogen peroxide. In the presence of peroxidase (EC 1.11.1.7) hydrogen peroxide oxidizes the chromogen, consisting of 4aminophenazone and 4-chlorophenol, to form a red coloured quinonemonoimine dye.

\section{Reaction principle:}

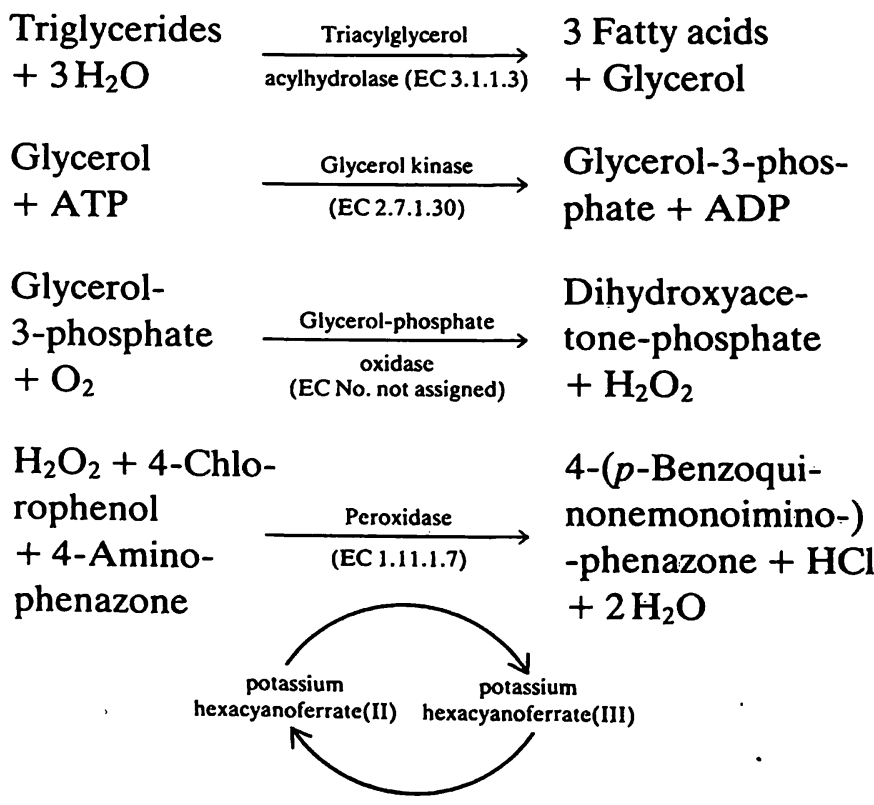

The absorbance of the quinonemonoimine dye is proportional to the concentration of triglycerides and free glycerol in the sample.
This simplified, fully enzymatic endpoint method for assay of total triglycerides offers several advantages:

- no need for a serum blank,

- absorbance reading in the visible region of the spectrum,

- good stability of the working solution,

- high precision and accuracy

- linearity up to $11.4 \mathrm{mmol} / \mathrm{l}$, or $10 \mathrm{~g} / \mathrm{l}$

- excellent applicability to automated analysers.

Because serum triglycerides are esterified with different fatty acids, the accurate determination of serum triglycerides requires the complete hydrolysis of triglycerides. Therefore we have developed a sensitive HPTLC-method which allows the quantitation of the extent of triglyceride cleavage under the conditions actually existing during routine assays of serum total triglycerides with enzymatic reagents. To demonstrate the complete oxidation of $L$ - $\alpha$-glycerol-phosphate to dihydroxyacetone-phosphate and hydrogen peroxide, and the formation of a homogeneous and definite quinonemonoimine dye under assay conditions we used HPLC-techniques.

$L$ - $\alpha$-glycerol-phosphate oxidase is highly specific for $L$ - $\alpha$-glycerol-phosphate, which is generated in a specific reaction from glycerol with glycerol kinase. The oxidative coupling in the last step under the catalytic influence of peroxidase is less specific. For example bilirubin has been described previously to interfere with the quantitation of hydrogen peroxide and decrease the amount of chromophore formed (11). For this reason, results obtained by determination of serum triglycerides tend to be lower than true triglyceride values. Therefore we optimized this method for measurement of triglyceride concentrations by use of potassium hexacyanoferrate(II) (7) to minimize bilirubin interferences.

\section{Materials and Methods}

Enzymatic assay

\section{Apparatus}

For UV- und visible light absorbance readings we used spectrophotometers from Eppendorf (Model 6118, Eppendorf Gerätebau, Hamburg, FRG) and Kontron (Model Uvicon 610.Cl, Kontron Analytical Division, Switzerland).

Chemicals

Tris(hydroxymethyl)-aminomethane, magnesium sulphate heptahydrate, sodium cholate and potassium hexacyanoferrate(II) dihydrate were all reagent grade materials and purchased from $E$. Merck, Darmstadt, FRG. EDTA, sodium salt (purum) ànd 4- 
chlorophenol (puriss.) were from Fluka, Buchs, Switzerland. 4Aminophenazone and Genapol ${ }^{\circledR}$ X-80 were from Hoechst AG, Frankfurt, FRG. Triacylglycerol acylhydrolase from Pseudomonas species, glycerol kinase from Bacillus stearothermophilus, horseradish peroxidase, $L-\alpha$-glycerol-phosphate oxidase from Pediococcus species and adenosine-5' -triphosphate were from Boehringer Mannheim GmbH, Mannheim, FRG.

\section{Control sera}

As control material we used Precinorm ${ }^{\otimes}$ U, Precipath ${ }^{\otimes}$ U, Precilip ${ }^{\oplus}$, Precilip ${ }^{\oplus}$ E.L. and Calibration serum from Boehringer Mannheim GmbH; Kontrollogen ${ }^{\otimes} \mathrm{L}$ and LP, from Behringwerke AG, Marburg, FRG; Validate $\mathrm{A}$ and Validate $\mathrm{N}$ from Goedecke AG, Freiburg, FRG; MONI-TROL I and MONITROL ${ }^{\circledR I I}$ from Merz and Dade, Department Germany, München, FRG; Hyland Q-PAK ${ }^{\otimes}$ II from Travenol Labratories, Lessines, Belgium.

\section{Reagent and standard}

The composition of buffer and enzymes/chromogen reagent is shown in table 1. To prepare the working solution the content of the enzymes/chromogen reagent must be dissolved with the buffer solution. This reagent is stable for at least $48 \mathrm{~h}$ at $20-25^{\circ} \mathrm{C}$, or 2 weeks at $2-8^{\circ} \mathrm{C}$.

As standard we used Precimat ${ }^{\circledR}$ Glycerol from Boehringer Mannheim containing $0.21 \mathrm{~g} /$ glycerol corresponding to $2.28 \mathrm{mmol} / 1$ triglycerides.

Tab. 1. Composition of triglyceride assay.

\begin{tabular}{llc}
\hline & Component & $\begin{array}{l}\text { Final } \\
\text { concentration }\end{array}$ \\
\hline \multirow{2}{*}{ Buffer } & Tris/HCl pH 7.6 & $150 \mathrm{mmol} / 1$ \\
& Magnesium sulphate heptahydrate & $17.5 \mathrm{mmol} / 1$ \\
& EDTA, sodium salt & $10.0 \mathrm{mmol} / 1$ \\
& Sodium cholate & $3.5 \mathrm{mmol} / 1$ \\
& Detergent & $1.2 \mathrm{~g} / 1$ \\
& 4-Chlorophenol & $3.5 \mathrm{mmol} / 1$ \\
& Potassium hexacyanoferrate(II) & $6.0 \mu \mathrm{mol} / 1$ \\
Enzymes/ & Adenosine 5'-triphosphate & $>0.5 \mathrm{mmol} / 1$ \\
chromogen & 4-Aminophenazone & $0.35 \mathrm{mmol} / 1$ \\
& Triacylglycerol acylhydrolase & $>3.0 \mathrm{kU} / 1$ \\
& Glycerol kinase & $>0.2 \mathrm{kU} / 1$ \\
& Glycerol-phosphate oxidase & $>2.5 \mathrm{kU} / 1$ \\
& Peroxidase & $>0.15 \mathrm{kU} / 1$ \\
& Flavine adenine dinucleotide & $6.0 \mu \mathrm{mol} / 1$ \\
\hline
\end{tabular}

\section{Assay procedure}

Add $20 \mu \mathrm{l}$ of the sample (serum, plasma or standard) to $2 \mathrm{ml}$ of the working solution. Mix and incubate for $10 \mathrm{~min}$ at $20-25^{\circ} \mathrm{C}$ or $37^{\circ} \mathrm{C}$. The absorbance is measured at $500 \mathrm{~nm}$ or $546 \mathrm{~nm}$ versus reagent blank.

\section{Comparison method}

The results of the enzymatic colour test were compared with those from an enzymatic ultraviolet method from Boehringer Mannheim.

\section{Chromatographic methods}

\section{Chémicals}

All reagents for sample pretreatment and chromatography were obtained from Merck Co. (Darmstadt, FRG) in the purest grade available with the following exceptions: Precilip control serum was from Boehringer Mannheim (Mannheim, FRG); cholesterol acetate, triolein, tristearin and glycerol-3-phosphate ( $\mathrm{Na}_{2}$-salt) were purchased from Serva (Heidelberg, FRG); dihydroxyacetone-phosphate (Li-salt) was from Sigma (Munich, FRG).

Instrumentation and procedures for the determination of the triglycerides in the assay

Centrifugation was carried out with a Labofuge II from $\mathrm{He}$ raeusChrist, Osterrode, FRG. Evaporations of the extraction solvent were performed under $\mathrm{N}_{2}$ using a Silli-Therm (Pierce Chemical Company, Rotterdam, The Netherlands). Silica-gel HPTLC plates were obtained from Merck Co. Chromatography was carried out with a CAMAG "U-Chamber". Scans of the chromatograms were obtained from a CAMAG TLC-scanner.

Redistilled chloroform and methanol were used for the preparation of the extraction solvent $\left(\mathrm{CHCl}_{3} / \mathrm{CH}_{3} \mathrm{OH}=1+1\right.$ by vol.).

Each analysis comprises at least 3 different sample extracts: Reacted sample " $S$ " represents the residual triglycerides after incubation of serum with the triglyceride reagent; the sample blank "SB" represents the amount of triglycerides originally present in the 1:100 diluted serum, and the reagent blank "RB" the background value caused by substrates from the reagent matrix showing chromatographic behaviour identical to that of the serum triglyceride fraction.

For the preparation of the reacted sample "S", add $45 \mu$ l of Precilip control serum to $4.45 \mathrm{ml}$ of triglyceride reagent. Mix and incubate according to the instructions of the test. Then add $28 \mathrm{ml}$ of the extraction solvent containing $0.207 \mathrm{mg} / \mathrm{l}$ cholesterol acetate as internal standard. Shake for $5 \mathrm{~min}$ and keep at $50^{\circ} \mathrm{C}$ for $15 \mathrm{~min}$. Remove the precipitate and evaporate the solvent. Dissolve the residue in $10 \mathrm{ml}$ methanol. Add $20 \mathrm{ml}$ of $n$-hexane and mix. Discard the lower phase and remove the hexane. Evaporate the upper phase and dissolve the residue in $50 \mu \mathrm{l} n$-hexane.

For the sample blank ("SB"), consecutively add $45 \mu \mathrm{l}$ of control serum and $4.45 \mathrm{ml}$ of triglyceride reagent to another $28 \mathrm{ml}$ of extraction solvent and proceed further as described for the reacted sample "S". For the reagent blank "RB" mix $4.45 \mathrm{ml}$ of triglyceride reagent with a third $28 \mathrm{ml}$ portion of extraction solvent.

\section{Circular high performance thin layer chromatography}

Apply $800 \mathrm{nl}$ aliquots of samples and blanks to silica-HPTLC plates. Develop the plates in circular mode with a total of $650 \mu \mathrm{l}$ hexane/diethylether/acetic acid $=60+12+15$ (by vol). Thereafter remove the solvent quantitatively. For staining, briefly dip the plate into a $5 \%$ aq. solution of $\mathrm{ZrOSO}_{4}$ and develop by heating at $120^{\circ} \mathrm{C}$. Thereby triglycerides and internal standard are converted into fluorescent compounds. Scan the lanes of samples and standards with the CAMAG scanner in the fluorescent mode (excitation wavelength $=366 \mathrm{~nm}$ ) and record the emission above $400 \mathrm{~nm}$.

Liquid chromatographic analysis of the conversion of glycerol to dihydroxyacetone phosphate

We used a liquid chromatograph, model HSRI 931, from Optilab, Stockholm, Sweden, equipped with a differential refractometer, model ERC-7510, from ERC Gesellschaft für den Vertrieb wissenschaftlicher Geräte mbH., Alteglofsheim/Opf., FRG.

The following stock solutions of standard compounds were prepared: glycerol $(13.4 \mathrm{mmol} / \mathrm{l})$, dihydroxyacetone-phosphate, $\mathrm{Li}$ salt $(6.70 \mathrm{mmol} / \mathrm{\Lambda})$ and glycerol-3-phosphate, $\mathrm{Naz}$-salt (3.12 
$\mathrm{mmol} / 1)$. Samples were prepared by adding glycerol up to 1.60 $\mathrm{mmol} / \mathrm{h}$ of the assay. Standards for peak identification and quantification were obtained by diluting the stock solutions in water. To monitor separation of dihydroxyacetone phosphate from glycerol3-phosphate, assay samples were spiked with amounts of glycerol3-phosphate from 0.12 to $0.93 \mathrm{mmol} /$ assay.

Standards, sample solutions and reagent blanks $(50 \mu l$ in each case) were injected on an ion exclusion guard column, coupled to an "organic acid column", type HPX-87H, $250 \times 7.8 \mathrm{~mm}$, both from BioRad, Munich, FRG. The columns were kept at $58^{\circ} \mathrm{C}$ and eluted with $50 \mathrm{mmol} / /$ sulfuric acid at a flow rate of $1.0 \mathrm{ml} / \mathrm{min}$. The optical bank of the detector was heated to $45^{\circ} \mathrm{C}$.

\section{Liquid chromatographic analysis of the colour reaction}

We injected $50 \mu \mathrm{l}$ of sample blanks and reacted samples $(210 \mathrm{mg}$ glycerol per liter of reagent) into a model 1084 A HPLC unit from Hewlett Packard, Waldbronn, FRG. Flavine adenine dinucleotide, 4-aminophenazone, 4-chlorophenol and the coloured reaction product were separated on a $5 \mu$ Lichrosorb RP-18 column, $250 \times 4 \mathrm{~mm}$ (Merck Co., Darmstadt, FRG), with a gradient from $0.01 \mathrm{~mol} / 1$ potassium phosphate buffer, $\mathrm{pH} 7.5$ to acetonitrile, at a flow rate of $1 \mathrm{ml} / \mathrm{min}$ and at room temperature. The effluent was monitored at $254 \mathrm{~nm}$ and at $500 \mathrm{~nm}$.

\section{Results}

\section{Assay characteristics}

\section{Absorbance}

The quinonimine dye, which is formed by oxidative coupling of 4-chlorophenol and 4-aminophenazone, shows under assay conditions a maximum of absorbance at $505 \mathrm{~nm}$.

\section{Colour development and colour stability}

The reaction rate was checked with different human sera, containing triglyceride concentrations up to $13.5 \mathrm{mmol} / \mathrm{l}$. The colour development was completed within $10 \mathrm{~min}$ at room temperature or at $37^{\circ} \mathrm{C}$.

The colour stability was studied in three different pools of human sera and in aqueous glycerol solutions. No important changes of absorbance at 500 $\mathrm{nm}$ and $546 \mathrm{~nm}$ could be detected during $60 \mathrm{~min}$ at room temperature or $30 \mathrm{~min}$ at $37^{\circ} \mathrm{C}$.

\section{Sensitivity}

The sensitivity of the method was investigated using aqueous glycerol solutions ranging from 1.1 to 11.4 $\mathrm{mmol} / \mathrm{l}$. At room temperature we recorded a response of $\Delta \mathrm{A}=0.115 \mathrm{per} \mathrm{mmol} / \mathrm{l}$ at $500 \mathrm{~nm}$ and $\Delta \mathrm{A}=0.084 \mathrm{per} \mathrm{mmol} / \mathrm{/}$ triglycerides at $546 \mathrm{~nm}$. Storage of the working reagent over a period of 48 hours at $20-25^{\circ} \mathrm{C}$ or two weeks at $2-8^{\circ} \mathrm{C}$ did not influence the sensitivity.

\section{Reagent blank}

The increase of reagent blank is less than $\Delta \mathrm{A}=$ 0.040 when the reagent is stored for 48 hours at 20$25^{\circ} \mathrm{C}$, and less than $\Delta \mathrm{A}=0.030$ when stored for two weeks at $2-8^{\circ} \mathrm{C}$.

\section{Linearity}

We tested the linearity with a human serum containing $14.0 \mathrm{mmol} / \mathrm{l}$ triglycerides, which was stepwise diluted with physiological saline. Figure 1 shows the absorbance at $500 \mathrm{~nm}$ and $546 \mathrm{~nm}$ versus increasing concentrations of triglycerides using a freshly prepared reagent and a reagent which was stored for 48 hours at $25^{\circ} \mathrm{C}$. The estimated curves are linear up to at least $11.4 \mathrm{mmol} / \mathrm{h}(\hat{=} 10 \mathrm{~g} / \mathrm{l})$.

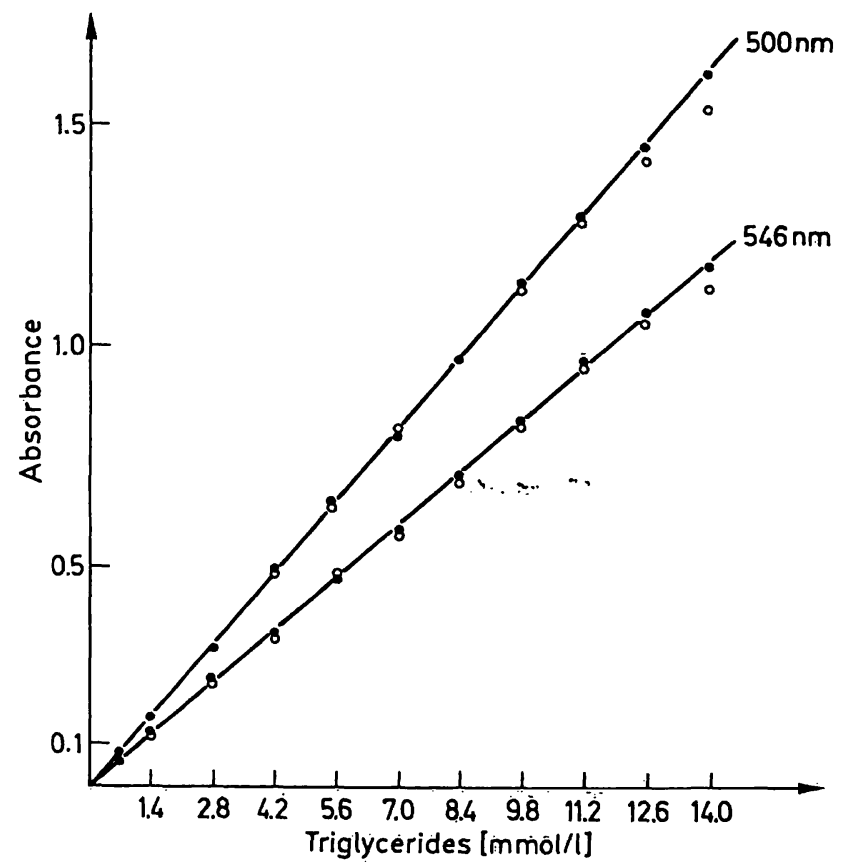

Fig. 1. Stepwise dilution of a human serum containing 14.0 mmol/ triglycerides with physiological saline. Absorbance readings at $500 \mathrm{~nm}$ and $546 \mathrm{~nm}$; incubation time $10 \mathrm{~min}$. - - Reagent freshly prepared

$\mathrm{O}-\mathrm{O}$ Reagent stored for 48 hours at $25^{\circ} \mathrm{C}$

\section{Precision}

Within run and day-to-day precision were determined by assay of three pooled human sera containing different concentrations of triglycerides. Standard deviation and coefficients of variation are shown in table 2 . 
Tab. 2. Precision data of triglyceride assay on different pooled human sera; absorbance reading at $546 \mathrm{~nm}$.

\begin{tabular}{lllll}
\hline Pooled sera & $\mathbf{n}$ & $\begin{array}{l}\text { Mean } \\
\text { value } \\
{[\mathrm{mmol} / \mathrm{l}]}\end{array}$ & $\mathrm{SD}$ & $\mathrm{CV}$ \\
& {$[\mathrm{mmol} / \mathrm{l}]$} & {$[\%]$} \\
\hline Within-run & & & & \\
Normal value & 20 & 0.76 & 0.017 & 2.2 \\
Normal value & 20 & 1.62 & 0.028 & 1.7 \\
High value & 20 & 6.97 & 0.063 & 0.9 \\
& & & & \\
Day-to-day & & & & \\
Normal value & 10 & 0.75 & 0.026 & 3.5 \\
Normal value & 10 & 1.60 & 0.046 & 2.1 \\
High value & 10 & 6.99 & 0.105 & 1.5 \\
\hline
\end{tabular}

\section{Accuracy}

The accuracy of the colorimetric method was estimated with 16 control sera of different producers. The claimed triglyceride values, determined by using an enzymatic UV-method, were between 0.73 and $3.46 \mathrm{mmol} / \mathrm{l}$. The results, presented in table 3 , show, that except Monitrol II, the recovery of the claimed values was in the range of $94 \%$ to $103 \%$.

Tab. 3. Analysis of several quality control sera; absorbance reading at $546 \mathrm{~nm}$.

\begin{tabular}{|c|c|c|c|c|}
\hline Control serum & Lot number & $\begin{array}{l}\text { Claimed } \\
\text { value }^{a} \text { ) } \\
{[\mathrm{mmol} / \mathrm{l}]}\end{array}$ & $\begin{array}{l}\text { Present } \\
\text { method } \\
{[\mathrm{mmol} / \mathrm{l}]}\end{array}$ & $\begin{array}{l}\text { Recov- } \\
\text { ery } \\
{[\%]}\end{array}$ \\
\hline 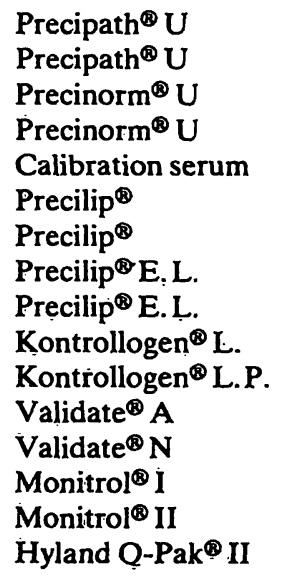 & $\begin{array}{c}21-511 \\
3-513 \\
09561 \\
4-570 \\
2-301 \\
5-371 \\
5-372 \\
3-305 \\
3-306 \\
623119 \text { A } \\
623206 \text { A } \\
2136090 \\
2235110 \\
\text { LTD 169 } \\
\text { PTD 68 } \\
\text { N22 A }\end{array}$ & $\begin{array}{l}0.97 \\
1.05 \\
1.09 \\
0.96 \\
1.60 \\
1.65 \\
1.75 \\
2.66 \\
3.46 \\
1.29 \\
1.44 \\
0.73 \\
0.93 \\
1.03 \\
0.86 \\
1.15\end{array}$ & $\begin{array}{l}0.91 \\
1.04 \\
1.05 \\
0.96 \\
1.58 \\
1.63 \\
1.78 \\
2.74 \\
3.53 \\
1.33 \\
1.47 \\
0.74 \\
0.96 \\
1.04 \\
0.75 \\
1.13\end{array}$ & $\begin{array}{r}94 \\
99 \\
96 \\
100 \\
99 \\
99 \\
102 \\
103 \\
102 \\
103 \\
102 \\
101 \\
103 \\
101 \\
87 \\
98\end{array}$ \\
\hline
\end{tabular}

a) for the fully enzymatic UV-method

\section{Lipaemic sera}

The influence of lipaemia was investigated with 8 human sera ranging from 13.7 to $20: 9 \mathrm{mmol} / \mathrm{t}$ triglycerides. The samples were diluted $1+1$ with physiological saline and the triglyceride values obtained with the colorimetric method were compared with an enzymatic UV-method from Boehringer Mannheim. Due to the turbidity clearing effect of the reagent we found no influence on the results of this assay by lipaemic sera. The recovery of triglyceride concentration in the UV-method was between $96 \%$ and $103 \%$. When the chromogenic system was omitted the difference between sample blank and reagent blank after the recommended incubation time was $\Delta \mathbf{A}<0.005$ corresponding to $<1 \%$ of the triglyceride values.

\section{Method comparison}

We estimated the triglyceride concentrations in 60 human sera ranging from 0.52 to $11.1 \mathrm{mmol} / \mathrm{l}$ and compared the results with an enzymatic UV-method from Boehringer Mannheim (fig. 2). The incubation temperature was $25^{\circ} \mathrm{C}$, absorbance readings were carried out at $546 \mathrm{~nm}$ (colorimetric method) and $365 \mathrm{~nm}$ (UV--method). The comparision of triglyceride values shows an excellent correlation between both methods with a correlation coefficient of 0.999 , a slope of 1.030 and an intercept of $-0.037 \mathrm{mmol} / \mathrm{l}$. In the comparison of the colorimetric method and the UV-method, the greatest observed differences were +9.5 and $-5.8 \%$.

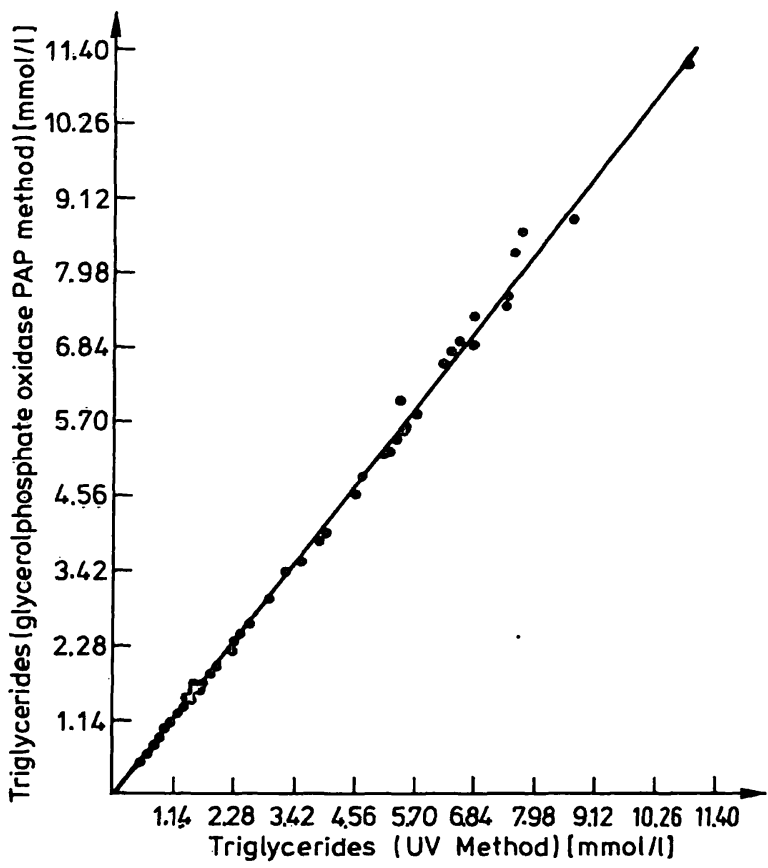

Fig. 2. Method comparison. Correlation between colorimetric method ( $y$; glycerolphosphate oxidase-p-aminophenazone (PAP) method) and enzymatic UV method ( $x$ ) for the determination of triglyceride concentrations in human sera. $\mathrm{n}=60$

$y=1.030 x-0.037$

$r=0.999$

$\overline{\mathrm{x}}=3.40 \mathrm{mmol} / \mathrm{h}$

$\bar{y}=3.46 \mathrm{mmol} / \mathrm{I}$ 


\section{Interference studies}

We investigated the interference of the serum metabolites bilirubin, haemoglobin, uric acid and glucose and the exogenous substances ascorbic acid and $\alpha$ methyldopa. Increasing amounts of the mentioned substances were added to pooled human sera containing triglyceride concentrations in the normal lev- el. The triglyceride value of each sample was determined in 5 replicates and changes in recovery were related to the pooled sera without added substances. To demonstrate the efficiency of potassium hexacyanoferrate(II) the interference of bilirubin was measured using a reagent mixture with and without this component. The results are shown in figures 3 and 4 .
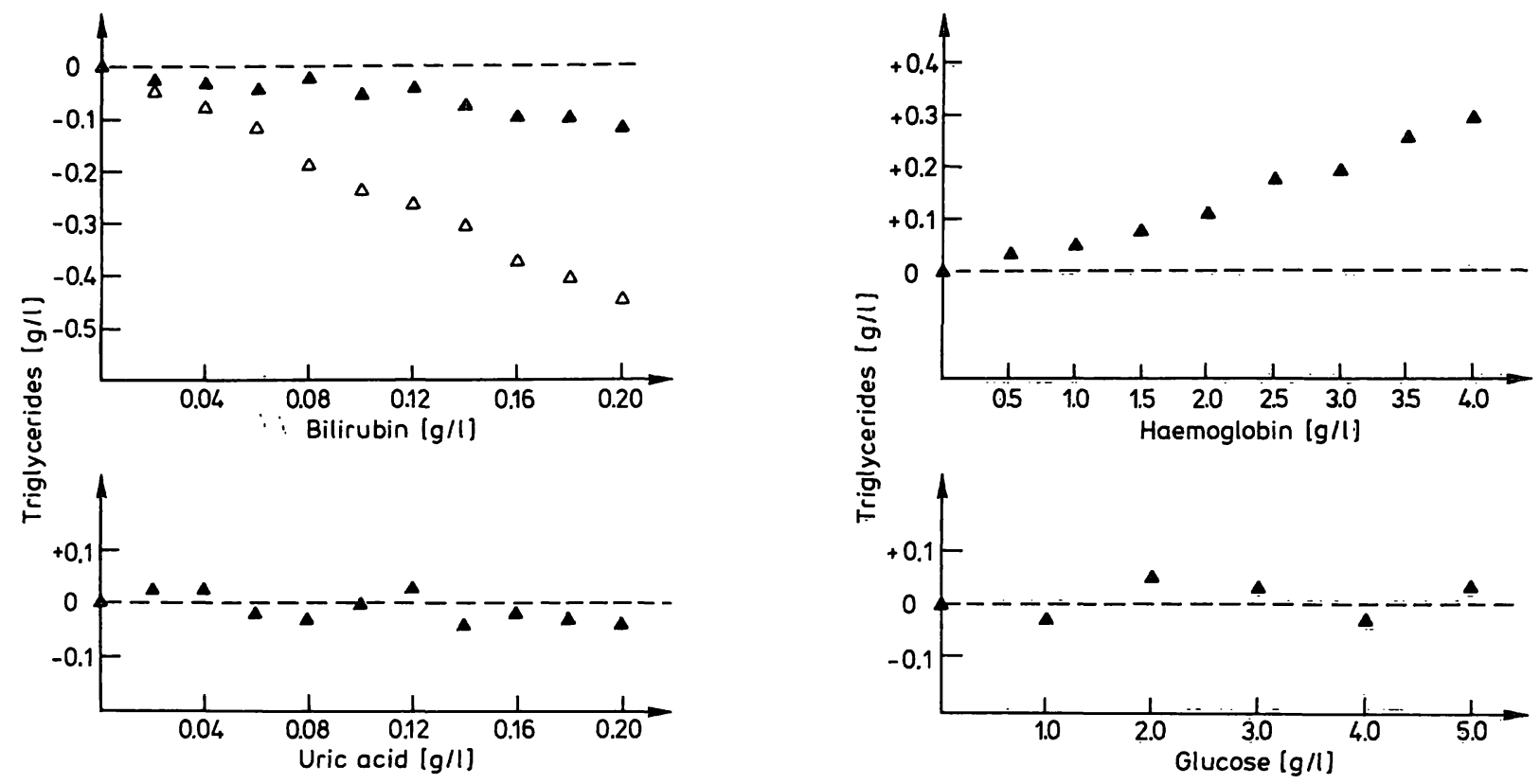

Fig. 3. Results of interference studies. Increasing quantities of bilirubin, haemoglobin, uric acid and glucose were added to pooled human sera. Changes in triglyceride values are related to the non-spiked sample. Absorbance readings at $546 \mathrm{~nm}$. $\Delta-\Delta$ Reagent containing $6 \mu \mathrm{mol} / \mathrm{l}$ potassium hexacyanoferrate(II)

$\Delta-\Delta$ Reagent without potassium hexacyanoferrate(II)

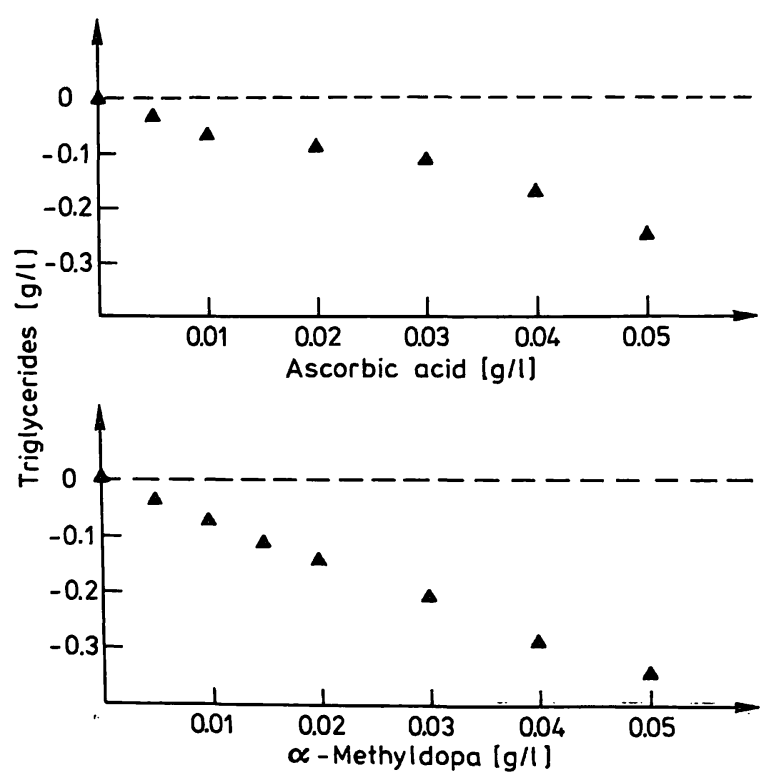

Fig. 4. Results of interference studies. Increasing quantities of ascorbic acid and $\alpha$-methyldopa were added to pooled human sera. Changes in triglyceride values are related to the non-spiked sample. Absorbance readings at $546 \mathrm{~nm}$.
Chromatographic monitoring of the cascade of enzymatic reactions

Since the accuracy of the triglyceride assay requires that each of the enzymatic reaction steps be complete and homogeneous, we monitored each step by non-enzymatic methods, in order to check these criteria.

Determination of unhydrolysed triglycerides in the assay (12)

The Folch procedure for extraction of lipids (13) was followed by a methanol/hexane partition. In this additional step the neutral lipids were extracted into the hexane phase and freed from matrix components which interfered with the thin-layer chromatographic determination of traces of unhydrolysed triglycerides in the assay (14). The hexane extract was subjected to the standard TLC proceduré för separating 
serum lipids into compound classes (15). The triglyceride spot was localized using triolein and tristearin as $\mathbf{R}_{\mathbf{f}}$-markers. By staining the neutral lipids with $\mathrm{ZrOSO}_{4}$ according to Segura (16) we obtained a limit of detection of about $1 \mathrm{ng}$ triglycerides per spot.

Since the signal response of triglycerides differs, depending on their content of unsaturated bonds, we used the 1:100 diluted serum itself ("sample blank") as the standard for quantification of the unhydrolysed triglycerides.

Figure 5 shows the densitometric profiles of sample, sample blank and reagent blank. The chromatogram of the reagent blank is the decisive test for the procedure of sample prepurification. It shows that no component from the assay matrix comigrates with the triglycerides. Comparison of the reacted sample with the sample blank demonstrates that remaining triglycerides are less than $0.3 \%$ of the initial amount of triglycerides in the serum. Thus, we conclude that serum triglycerides are hydrolysed completely to glycerol and fatty acids in this assay.
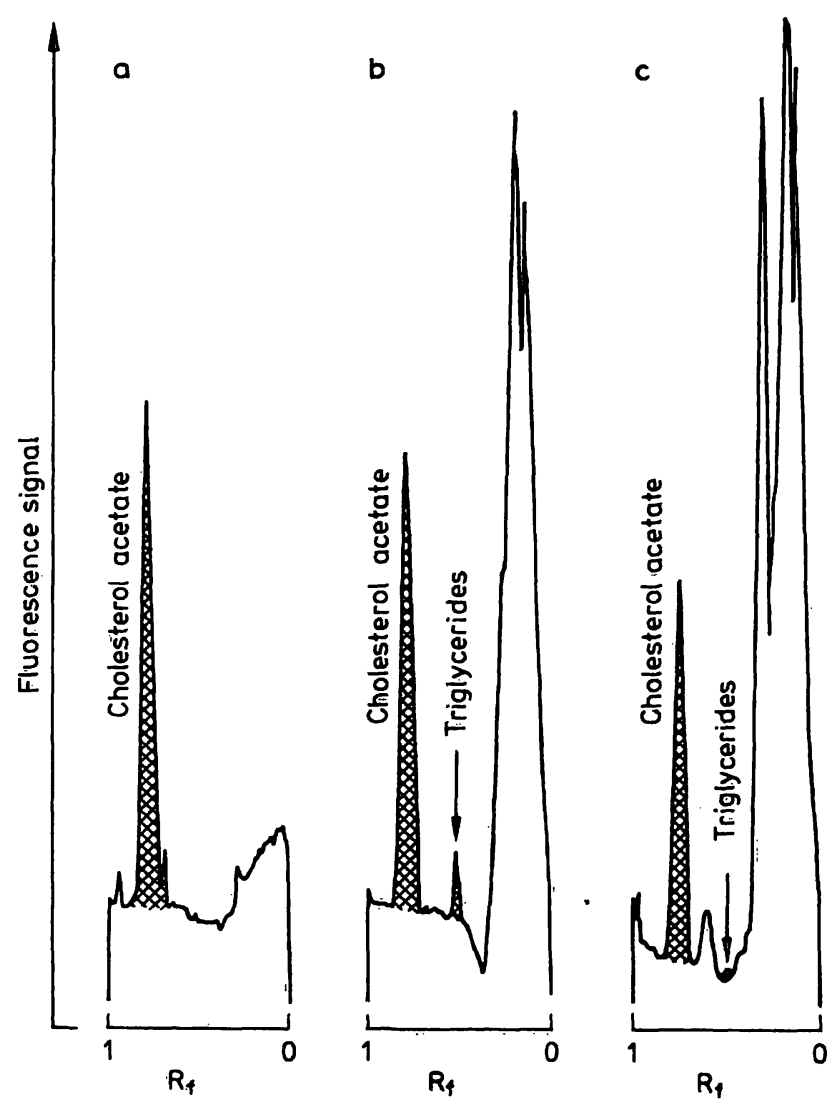

Fig. 5. Thin-layer chromatographic determination of triglycerides in the colorimetric triglyceride assay. Reagent blank (a) shows the absence of matrix interference; the sample blank (b) was prepared with $1: 100$ diluted serum and served as quantitative standard ( $1 \%$ standard); in the assay sample (c) $<0.3 \%$ of the serum triglycerides remained unhydrolysed. Internal standard: cholesterol acetate.
Conversion of glycerol to dihydroxyacetone-phosphate

From the various types of anion exchange and ionpair reversed phase chromatographic systems which were tried, only chromatography on the BioRad "organic acid column" was suited for the separation of dihydroxyacetone-phosphate from its precursors, glycerol and glycerol-3-phosphate, and from the other components of the assay mixture. The sulphuric acid concentration of the eluent had to be increased from the conventional $0.005 \mathrm{~mol} / 1$ to 0.05 $\mathrm{mol} / \mathrm{l}$ to improve this separation (17). Refractometric detection was mandatory. To provide for sufficient sensitivity, addition of glycerol to the reagent far beyond the linear measuring range of the enzymatic assay was required. Therefore, limiting reagent ingredients were increased for these experiments.

Figure 6 shows chromatograms obtained from a standard solution containing dihydroxyacetonephosphate, glycerol-3-phosphate and glycerol (a), a reagent blank (b), an assay reacted with $1.60 \mathrm{mmol} / \mathrm{l}$ glycerol (c) and an assay spiked with glycerol-3phosphate (d). Comparison of the reagent blank with both assay and spiked assay demonstrated that detection of reaction intermediates and product is not impaired by the assay matrix. The reacted assay contains neither glycerol-3-phosphate nor residual glycerol.

The limit of detection for both glycerol and its phosphate was found to be $0.06 \mathrm{mmol} / \mathrm{l}$ of the injected solution. This corresponds to $4 \%$ of the concentration of glycerol employed in the assay.

\section{Analysis of the colour reaction}

Samples were injected on a reversed phase column without pretreatment. With the acetonitrile gradient, flavine adenine dinucleotide, 4-aminophenazone, the colour product and 4-chlorophenol were eluted as distinct, symmetric peaks. Addition of phosphate buffer to the eluent was necessary, since these compounds (except 4-chlorophenol) carry electric charges (18). The chromatograms in figure 7 represent the separation of the reaction blank and the reacted assay after addition of glycerol, monitored both at 254 and $500 \mathrm{~nm}$. At $254 \mathrm{~nm}$ all the above mentioned compounds are recorded in the eluate, whereas at $500 \mathrm{~nm} \mathrm{FAD}$ and the coloured reaction product are detected selectively. At both wavelengths only one additional peak appears after enzymatic reaction - most clearly to be seen from the signal traces at $500 \mathrm{~nm}$. This shows that the colour forming reaction step leads to a single definite product. 

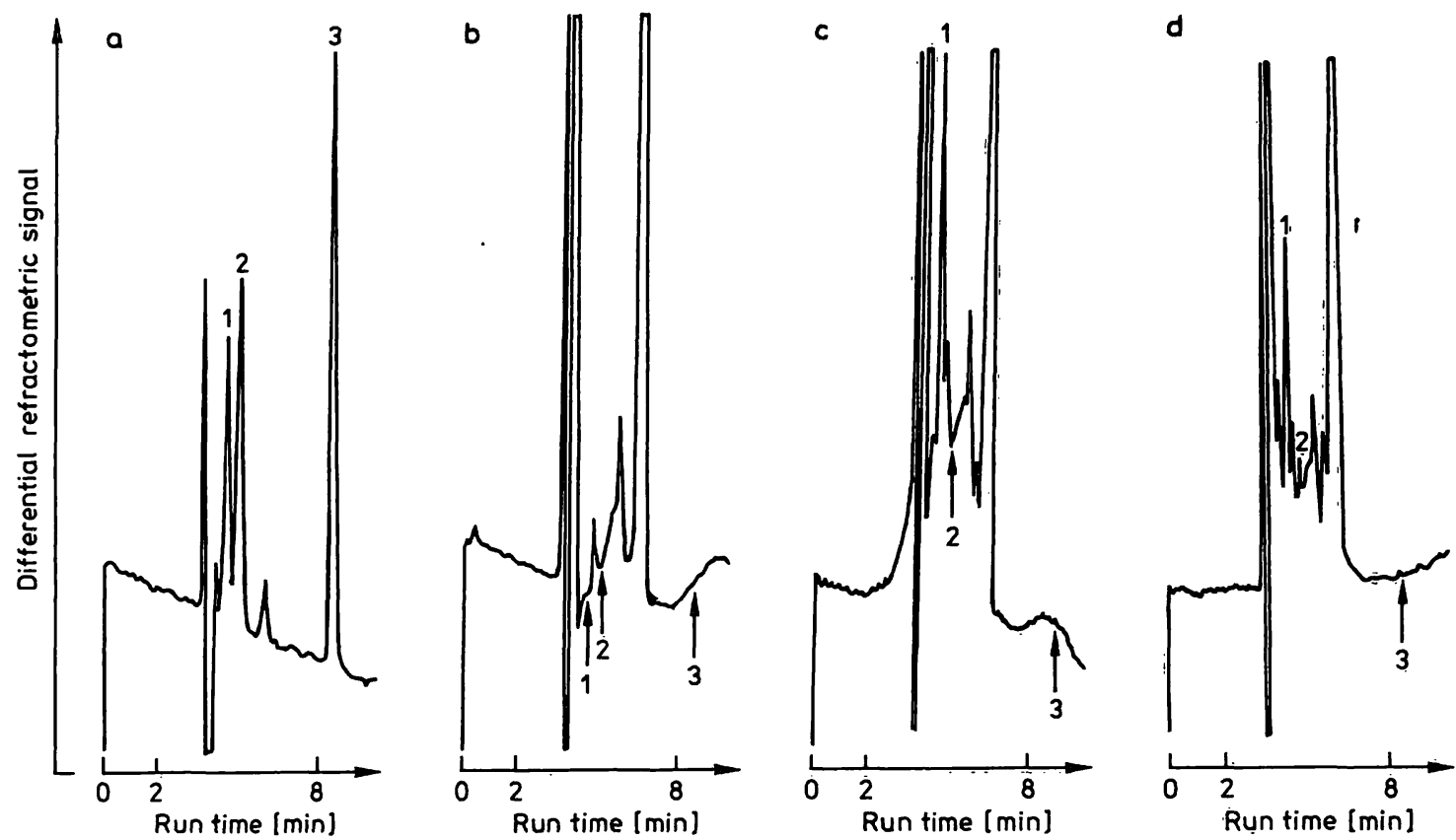

Fig. 6. Monitoring of the complete conversion of glycerol (3) via glycerol-3-phosphate (2) to dihydroxyacetone-phosphate (1) by HPLC. a: separation of a mixture of dihydroxyacetone phosphate, glycerol-3-phosphate and glycerol.

b: chromatogram of the reagent blank shows lack of matrix interference with the determination of the 3 compounds.

c: sample assay contains neither glycerol-3-phosphate nor glycerol.

d: sample assay spiked with glycerol-3-phosphate. Broken arrows indicate position of reaction partners missing in the respective chromatogram.
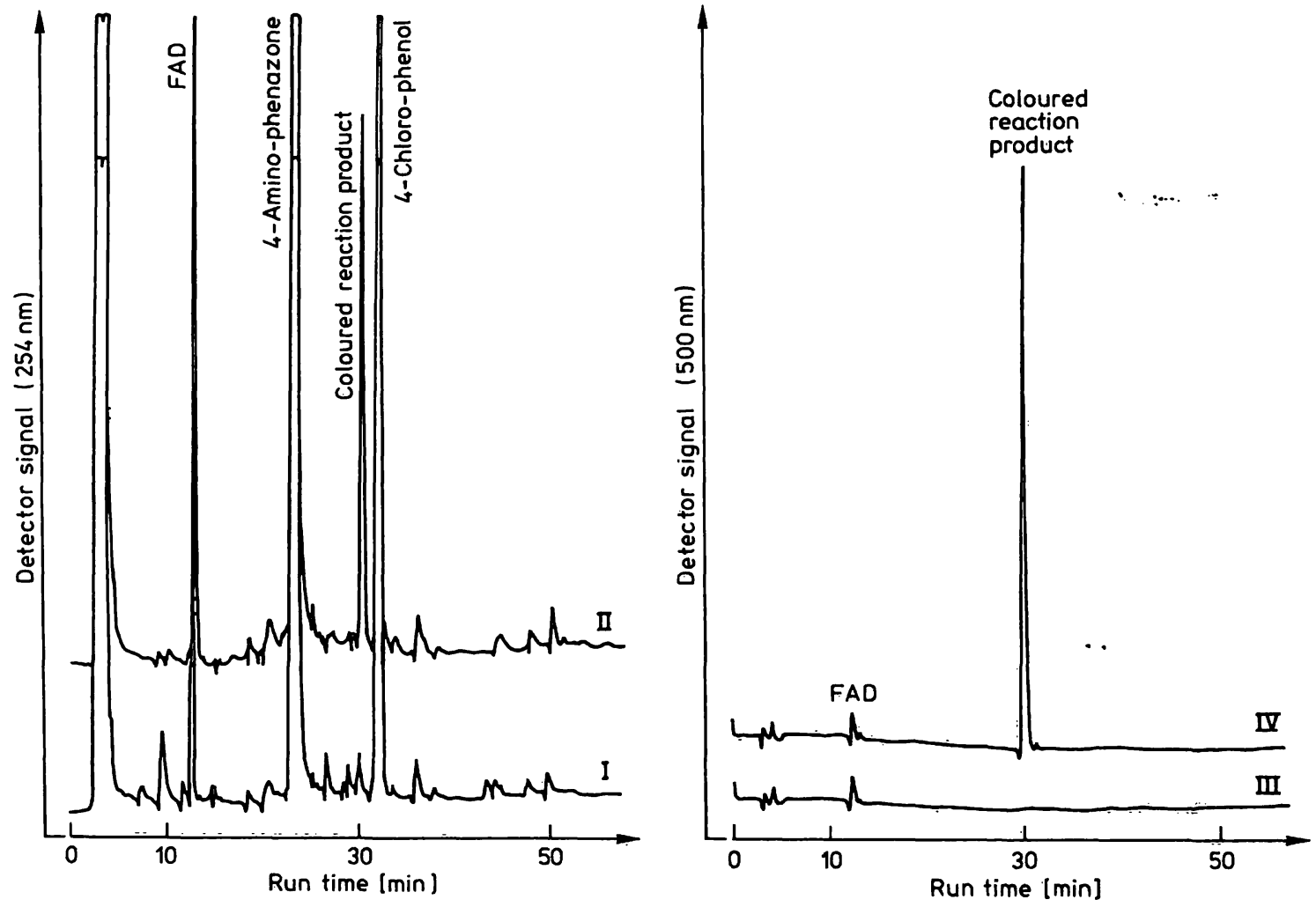

Fig. 7. Evidence of the homogeneous course of the colour forming reaction by HPLC.
I: Reagent blank at $254 \mathrm{~nm}$
II: assay sample at $254 \mathrm{~nm}$
III: reagent blank at $500 \mathrm{~nm}$
IV: assay sample at $500 \mathrm{~nm}$

At both wavelengths only one reaction product was found. 


\section{Discussion}

A major factor in the accuracy of an enzymatic determination of serum triglycerides is the complete hydrolysis of triglycerides by triacylglycerol acylhydrolase. Furthermore there must be no interfering side reactions during phosphorylation of the liberated glycerol by glycerol kinase and oxidation of glycerol-3-phosphate by $L$ - $\alpha$-glycerol-phosphate oxidase to dihydroxyacetone-phosphate with the equimolar consumption of oxygen and the concomitant formation of hydrogen peroxide. To demonstrate the homogeneous course of these enzymatic reactions, we developed a HPTLC-technique for monitoring the complete hydrolysis of serum triglycerides, and a HPLC-method for monitoring the total conversion of glycerol to dihydroxyacetone-phosphate. Because the final peroxidase-dependent oxidative coupling is relatively unspecific, we optimized the assay conditions to ensure that the absorbance in the visible region was caused by one homogeneous reaction product. The formation of an uniform quinonemonoimine dye was proved with a HPLCmethod.

We optimized the reagent composition of this quantitative colorimetric method with regard to complete colour development within $10 \mathrm{~min}$ at $20-25^{\circ} \mathrm{C}$ and $37^{\circ} \mathrm{C}$, maximum colour stability and minimum reagent blank. The analytical sensitivity of the indicator reaction permits a good differentiation of triglyceride concentrations even in the very low range.

The wide range of linearity up to $10 \mathrm{~g} / \mathrm{l}$ or 11.4 $\mathrm{mmol} / 1$ is also fulfilled when the working reagent is stored for 48 hours at $20-25^{\circ} \mathrm{C}$ or two weeks at 2$8^{\circ} \mathrm{C}$, which is of great importance under routine assay conditions.

The ability to measure lipaemic sera without sample pretreatment and without a sample blank is due to the use of an efficient turbidity clearing system, consisting of triacylglycerol acylhydrolase, sodium cho- late, detergent and an appropriate ionic strength, which also prevents the appearance of turbidity during the reaction time at both incubation temperatures.

The correlation between the colorimetric method and an enzymatic UV-assay is highly significant in the whole range of linearity.

Using Trinder systems for the detection of hydrogen peroxide, bilirubin has been reported to interact in the peroxidase-catalysed reaction by competing for hydrogen peroxide, which results in lower triglyceride values. Positive spectral interference can be lessened by measuring at a wavelength of $500 \mathrm{~nm}$ or higher (11). The chemical interference could be minimized by use of potassium hexacyanoferrate(II) as previously described (7). Up to serum concentrations of $150 \mathrm{mg} / \mathrm{l}$ we found no significant influence.

Haemoglobin not only acts as a pseudoperoxidase but also causes a positive spectral interference in the visible range: However this effect was negligible when serum concentrations were less than $2 \mathrm{~g} / \mathrm{l}$.

With the exception of ascorbic acid and $\alpha$-methyldo$\mathrm{pa}$, for which negative interferences were borderline, we found no disturbing effects on the assay of triglycerides by common drugs at concentrations in excess of clinically relevant serum concentrations.

In conclusion, the chemical and biochemical basis for this colorimetric method can be clearly specified. This is the preliminary condition for an accurate and reliable assay. Because of the simple handling and the excellent applicability to automated instruments the proposed method is well suitable for clinical routine laboratories.

\section{Acknowledgements}

We thank Miss B. Wiedemann, Mrs. L. Müller, Mr. J. Finke and Mr. T. Dülffer for their excellent technical assistance.

\section{References}

1. Wahlefeld, A. W. (1974) Triglycerides. In: Methods of Enzymatic Analysis (Bergmeyer, H.-U., ed:) Academic Press, Inc., New York, pp. 1831-1835.

2. Enzyme Nomenclature, Recommendations (1978) of the Nomenclature Committee of the International Union of Biochemistry (IUB). Academic Press, Inc. New York 1979.

3. Uwajima, T., Akita, H., Ito, K., Misaka, A., Aisaka, K. \& Terada, O. (1979) Agric. Biol. Chem. 43, 2633-2634

4. Esders, T. W. \& Michrina, C. A. (1979) J. Biol. Chem. 254, 2710-2715.

5. Megraw, R. E., Dunn, D. E. \& Biggs, H. G. (1979) Clin. Chem. 25, 273-278.
6. Spayd, R. W., Bruschi, B., Burdick, B. A., Dappen, G. M. Eikenberry, J. N., Esders, T. W., Figueras, J., Goodhue. C. T., LaRossa, D. D., Nelson, R. W., Rand, R. N. \& Wu, T.-W. (1978) Clin. Chem. 24, 1343-1350.

7. Fossati, P. \& Prencipe, L. (1982) Clin. Chem. 28, 20772080.

8. Henkel, E. \& Stoltz, M. (1982) Fresenius Z. Anal. Chem. $311,451-452$.

9. Mc Gowan, M. W., Artiss, J. D., Strandbergh, D. R. \& Zak, B. (1983) Clin. Chem. 29, 538-542.

10. Trinder, P. (1969) Ann. Clin. Biochem. 6, 24.

11. Witte, D. L., Brown, L. F. \& Feld, R. D. (1978) Clin. Chem. 24, 1178-1782. 
12. Müller, L. Personal Communication.

13. Folch, J., Less, M. \& Sloane-Stanley, G. H. (1957) J. Biol. Chem. 226, 497-509.

14. Kupke, I. R. \& Zeigner, S. (1978) J. Chromatogr. 146, 261271.
15. Finke, J., Pẹrsonal Communication.

16. Segura, R. \& Navarro, X. (1981) J. Chromatogr. 217, 329340.

17. Kratzer, M. \& Hägele, E. O. To be Published.

18. Duelffer, T. Personal Communication.

Dr. U. Nägele

Boehringer Mannheim GmbH

Biochemica Werk Tutzing

Bahnhofstraße 9-15

D-8132 Tutzing 